\title{
REVITALIZACE HRADNÍ ZŘÍCENINY ROKŠTEJN A PERSPEKTIVY JEJÍHO KULTURNÍHO VYUŽITÍ
}

\author{
ZDENĚK MĚŘÍNSKÝ - MIROSLAV PLAČEK
}

\begin{abstract}
Abstrakt: Podány jsou historie a postup výzkumných praci za 33 sezón od roku 1981 do současnosti, cíle projektu a jeho výsledky, stručná informace o nálezech včetně ekofaktů, popis lokality a stavební vývoj fází IA a IB od prvé zmínky o lokalitě k roku 1289 do poloviny 14. století s přehledem šlechtických vlastníkü, doba druhé poloviny 14. stoleti, kdy hrad náležel moravské lucemburské sekundogeniture, přes dobu Valdštejnů v prvni třetině 15. století, pobořeni a částečné opuštění lokality za husitských válek, částečná obnova $v$ době poloviny 15. stoleti a zázemi hradu. Zvláštni pozornost je potom věnována vypracováni projektu „, Konzervace a stabilizace konstrukci hradu Rokštejn“, jehož realizace začala v roce 2003 a dnes spěje do závěrečné fáze. Popsána je koncepce revitalizace zř́ceniny vycházejicí ze současných trendi̊ památkové péče, která je dílem Ing. J. Vinaře. Naznačeny jsou také perspektivy využití zříceniny ke kulturním a osvětovým účelùm.
\end{abstract}

Klíčová slova: hrad Rokštejn - Morava - archeologický a stavebně historický výzkum - památkové zabezpečeni a revitalizace zř́ceniny.

\section{Revitalization of the Rokštejn Castle Ruin and the Perspectives of its Cultural Usage}

Abstract: This paper charts the history and progress of research spanning 33 seasons, started in 1981, as well as the targets and results of the project. It presents brief information about finds including ecofacts, the description of the site and its building development in phases IA and IB from the first mention of the location in 1289 until the mid-14th century, with an overview of the castle's aristocratic owners, its history in the second half of the 14th century when the castle was in the hands of the Moravian Luxembourg secundogeniture, through the Valdštejn ownership in the first third of the 15th century, the burning down of the castle and partial abandonment of the site during the Hussite wars, its partial restoration in the mid-15th century and the castle's economic hinterland. Special attention is also devoted to the project "The Conservation and Restructuring of the Rokštejn Castle Constructions"; the project was launched in 2003 and is now entering its final phase. The article introduces a concept of the revitalization of ruins of architecture, the work of Ing. J. Vinar based on the modern trends in heritage care. Perspectives of the use of the castle ruin for cultural and educational activities are outlined as well.

Key words: Rokštejn castle-Moravia-archaeological and building-historical research-heritage conservation and revitalization of a castle ruin.

V roce 1981 byl v souvislosti s tehdy prosazovanou výstavbou vodního díla Střížov zahájen jako záchranná akce výzkum zříceniny hradu Rokštejna u Panské Lhoty (město Brtnice, okr. Jihlava, Morava). Výstavba přehrady nebyla naštěstí dosud realizována. Znamenala by likvidaci nenahraditelné kulturní památky, jejíž význam z hlediska architektonického vývoje i politických událostí, zejména 14. až první třetiny 15. století, je daleko větší, než se soudilo před započetím záchranného výzkumu. Zároveň by došlo $\mathrm{k}$ vážnému narušení přírodního prostředí a zničení celé scenérie romantického údolí dolního toku Brtnice až po stejnojmenné město (srov. např. Měřínský 1985; 1986; 1988; 1988a, 54, 67-71, 76-88; 1988b, 33, 40; 1991; 1991a; 1992; 1994,$97 ; 2007,6$, tam pozn. č. 7-10 na s. 8-11, na s. 136-142 vybrané prameny a literatura; 2011, 37; 2011a, 224-226; 2014, 471-472; Měřínský-Plaček 1989, 3; 2010-2011, 125-128; MěřínskýPlaček-Vlach 2009, 17-23; Měřínský-Zumpfe 2002, 9, 16; Plaček 1996, ${ }^{2} 1999,300 ; 2001,539$ ).

Záchranný výzkum hradu Rokštejn se tak rozrostl během dosud proběhlých třiatřiceti výzkumných sezón (r. 1997 byl výzkum přerušen) v rozsáhlý systematický výzkumný projekt sledující všechny aspekty spojené se stavebně historickým vývojem objektu, chronologií materiální kultury vrcholného středověku, životem obyvatel hradu a jejich společenským postavením i hospodářskými vazbami, ekologií a prírodním prostředím regionu ve středověku atd. Cílem výzkumu bylo získat co nejpodrobnější obraz o půdorysném schématu lokality a jejím stavebně historickém vývoji a pochopitelně celou odkrytou situaci podrobně zdokumentovat (obr. 1). 
Dále měl výzkum upřesnit osudy hradu v průběhu 13. až 15. století, dobu jeho vzniku a zániku a rovněž zasadit dějiny lokality do širších souvislostí historie regionu Jihlavska i celé Moravy. To je však pouze jedna stránka úkolu, nebot' poznatky z výzkumu by měly přispět také k dalšímu zpřesnění chronologie a klasifikace, stejně jako k prohloubení dosavadního poznání hmotné kultury středověku. Podstatné je též postižení života na obdobných objektech a rovněž jejich postavení jako center feudálních panství, vazeb na hospodaření velkostatků, vlivů na vesnice ve vlastnictví majitelů hradu včetně vývoje jejich majetkové držby a život poddaného lidu na nich. Rozsáhlý soubor nalezených hmotných památek obsahuje i materiál důležitý pro studium vývoje lesa a prrírodních poměrů vůbec, stravy obyvatel hradu, pěstovaných plodin, domácích i lovených zvířat, řemesel apod. (ze shrnujících prací srov. např. Měřínský-Plaček 1989, 3; Měřínský 1988,$241 ; 1991,65-82 ; 1991 \mathrm{a}, 413 ; 1994,97 ; 2007,6-8$, tam na s. 136-142 vybrané prameny a literatura; 2011, 37-39; 2014, 471-473; Měřínský-Zumpfe 2002, 9, 16).

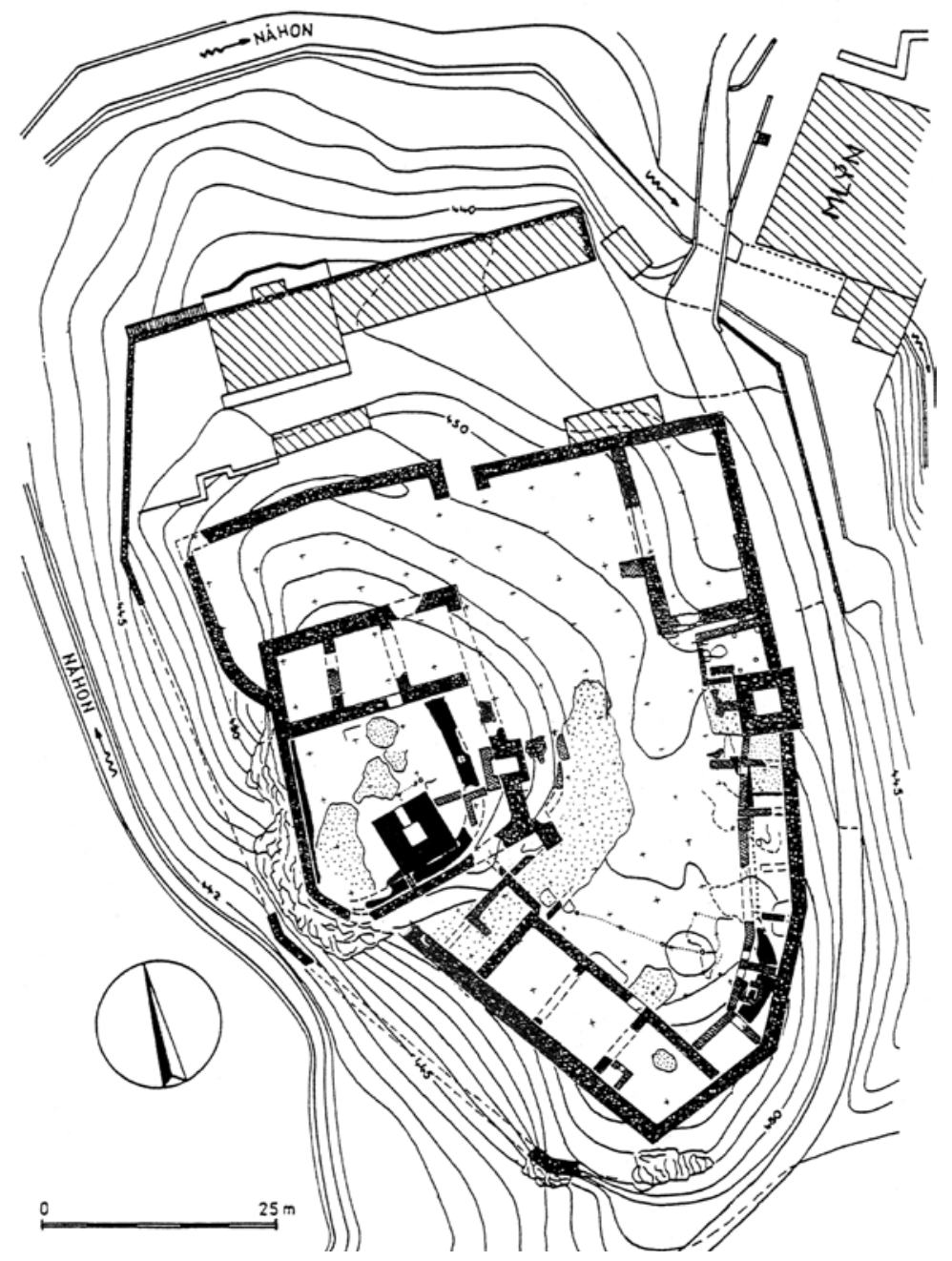

Obr. 1. Rokštejn, k. ú. Panská Lhota, město Brtnice. Půdorys hradu s výsledky výzkumu po sezóně 2011. Černě - zdivo fáze IA a IB, zrnitě - II. markraběcí fáze, mřižovaně - III. valdštejnská fáze, šrafovaně - novověké objekty, tečkovaně - umělé zahloubené středověké deprese.

Abb. 1. Rokštejn, Katastergebiet Panská Lhota, Stadt Brtnice. Grundriss der Burg mit Grabungsergebnissen nach der Grabungssaison 2011. Rot - Mauerwerk der Phase IA und IB, gekörnt - II. Markgrafschaftsphase, gerastert - III. Wallensteinische Phase, schraffiert - neuzeitliche Objekte, punktiert - künstlich eingetiefte mittelalterliche Depression. 
V letech 1981-1988 prováděl výzkum Archeologický ústav ČSAV v Brně, další sezóny 1989-1991 Moravské zemské muzeum v Brně a od tohoto data FF MU v Brně, zprvu jeho Historický ústav a od roku 1996 Ústav archeologie a muzeologie. Během dosud probíhajícího výzkumu se podařilo odkrýt z jádra hradu dolní palác, celý areál horního hradu a jižní i střední úsek nádvoří hradu dolního včetně větší části budovy $\mathrm{C}$ v severovýchodním koutu dolního hradu zhruba o výměře $2250 \mathrm{~m}^{2}$. Zbývá ještě prozkoumat asi $650 \mathrm{~m}^{2}$ severní části dolního hradu, a rozpracován je výzkum prostoru severně od dolního paláce mezi ním a horním hradem. Dokončen bude výzkum prostoru parkánu západně od dolního paláce a následně i jeho průběh na západním svahu od horního paláce a podobně i na jižní a východní straně dolního hradu o výměře zhruba $325 \mathrm{~m}^{2}$ (srov. Měřínský 1991a, 413; 2007, 8-10, pozn. č. 8-10 s lit.; 2011, 39, 45; 2014, 473; Měřínský-Zumpfe 2002, 9, 16, tam další lit.; Měřínský-Plaček 2010-2011, 125; Měřínský-Plaček-Vlach 2009, 18-19).

Lokalita se nachází v údolí dolního toku říčky Brtnice asi $1 \mathrm{~km}$ od jejího soutoku s Jihlavou mezi obcemi Přímělkov a Panská Lhota (obě město Brtnice, okr. Jihlava) na katastrálním území druhé obce. Jako nemovitá kulturní památka je zřícenina zapsána v př́ílušném seznamu pod rejstř́ikem č. 21329/7-5055. Jádro hradu je situováno na skalnatém suku obtékaném Brtnicí a vyvýšeném asi 16 m nade dnem údolí (Měřínský 1988, 241, 246; 1991a, 413; 1994, 97; 2007, 58; 2011, 39; 2014, 474; Měřínský-Plaček 1989, 17; 2010-2011, 125; Měřínský-Plaček-Vlach 2009, 19). Poprvé se hrad připomíná v roce 1289 (CDM VII, 776-777 č. 147; Regesta VIII, 640 č. 1485) a na základě analýzy písemných pramenů, stavebně historického průzkumu i archeologického výzkumu (obr. 2) lze výstavbu hradního jádra vročit do 70. až 80. let 13. století (fáze IA) a první zdokonalení sídla včetně výstavby dosud stojící hranolové věže horního hradu na základě dendrochronologických dat (Měřínský 2011a, 224; srov. Šabatová-Chlubna 2009) do doby po roce 1307 (fáze IB). Kolem roku 1359, možná však již krátce po roce 1350, se hrad dostal do rukou bratra Karla IV., moravského markraběte Jana Jindřicha, a stal se ústředím zdejšího zeměpanského zboží s hospodářským centrem v Brtnici. Po smrti Jana Jindřicha v roce 1375 vedli jeho synové Jošt, Jan Soběslav a Prokop spory o dědictví po otci a rokštejnské zboží nakonec získal Prokop (fáze II, 2. polovina 14. století), ale již v rozmezí let 1396-1399 hrad přešel do držby Valdštejnů (1. třetina 15. století). Přesné datum zániku hradu se prozatím nepodařilo stanovit, ale stalo se tak mezi lety 1423 a 1436. Poboření a opuštění Rokštejna za husitských válek dokládají celkem spolehlivě dosavadní výsledky archeologického výzkumu lokality i analýza hmotných památek a písemných pramenů (obr. 3).

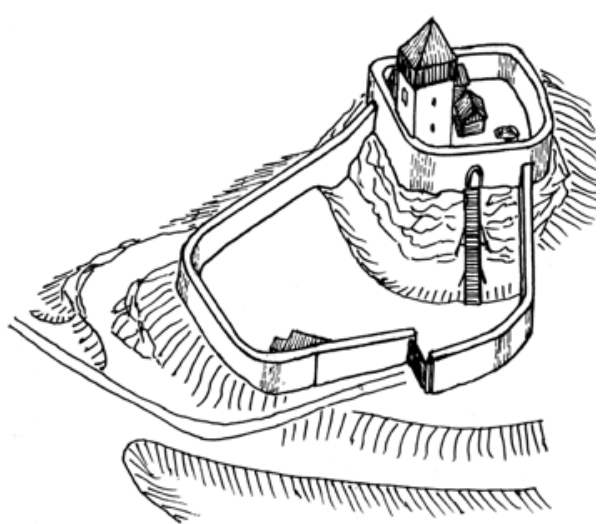

Obr. 2. Rokštejn, k. ú. Panská Lhota, město Brtnice. Pokus o rekonstrukci podoby hradu okolo roku 1320. Kresba M. Plaček. Abb. 2. Rokštejn, Katastergebiet Panská Lhota, Stadt Brtnice. Versuch einer Rekonstruktion dessen, wie die Burg um 1320 ausgesehen hat. Zeichnung M. Plaček.

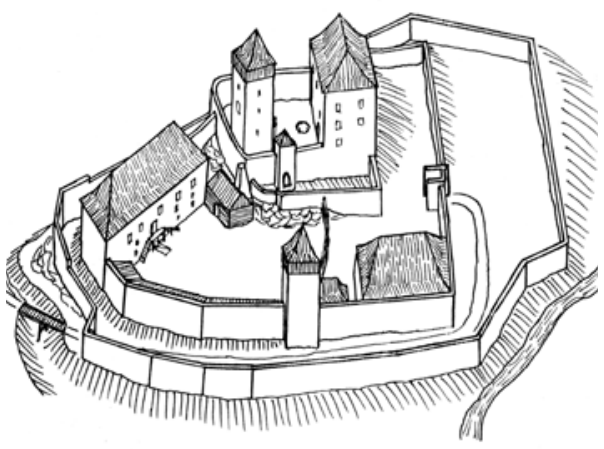

Obr. 3. Rokštejn, k. ú. Panská Lhota, město Brtnice. Pokus o rekonstrukci podoby hradu okolo roku 1420. Kresba M. Plaček. Abb. 3. Rokštejn, Katastergebiet Panská Lhota, Stadt Brtnice. Versuch einer Rekonstruktion dessen, wie die Burg um 1420 ausgesehen hat. Zeichnung $M$. Plaček. 
Hrad však nebyl patrně za husitských válek zbořen úplně, což vyplývá i ze stavu jeho dnešního zachování. Spíše vyhořel, byly pobořeny části hradeb a zůstal opuštěný. Ve 40. nebo 50. letech 15. století došlo zřejmě k nouzovému zajištění destruovaných úseků hradební zdi a okolí brány do horního hradu valem a palisádou. Na základě archeologického výzkumu lze říci, že do obyvatelného stavu tehdy asi uvedli nejméně budovu $\mathrm{C} v$ severovýchodním nároží dolního hradu a provizorně obyvatelné mohly zůstat i další objekty (fáze IV). V 50. a v první polovině 60. let 15. století jsou též na hradě datovány některé písemné dokumenty či na hrad směřují. Středisko valdštejnského panství se však již během husitských válek přesunulo z Rokštejna na Brtnici a Zdeněk z Valdštejna také operoval a řídil své akce ze Sádku severně od Moravských Budějovic, který byl rovněž v jeho moci. Protože Rokštejn na skalním suku v údolí Brtnice $\mathrm{s}$ rozvojem palných zbraní přestal $\mathrm{z}$ vojenského hlediska vyhovovat a $\mathrm{v}$ době změn hospodár̆ského nazírání šlechty a počátků jejího hospodaření ve vlastní režii nestačil ani jako centrum panství, staví Valdštejni nový hrad přímo v tržním městečku Brtnici. Krom výše zmiňovaného provizorního využití byl Rokštejn ponechán svému osudu. Výstavbu hradu v Brtnici dokládá stížnost Jihlavských k markraběti Albrechtovi z roku 1436 (Měřínský 1988, 241-242; 1991, 6571; 1991a, 413-415; 1994, 97-100; 2007, 13-56; 2011, 39-41; 2014, 474-475; Měřínský-Zumpfe 2002, 10-12; Měřínský-Plaček 1989, 4-16; 2010-2011, 125-129; Měřínský-Plaček-Vlach 2009, 19; Mazáčková 2011, 73-76).

Třiatřicet let trvající plošný odkryv hradu, který patří k největším výzkumům středověkých památek tohoto druhu nejen u nás, ale i v rámci středoevropském, přinesl zcela nové a od dřivějších názorů odlišné poznatky o dispozičním členění objektu, stavebním vývoji lokality a jeho jednotlivých etapách. Jako prŕíklad můžeme uvést prozatím v našem prostředí unikátní nález stavební oběti. Při jihozápadním nároží hlavní věže nejstaršího hradu rodu Stř́ižovců (k nim Vohryzek 2012, 67-73) bylo do skalní rozsedliny (obj. 130, čtv. 4/9 a 4/10) uloženo tělo novorozence. Kompletně zachovalá kostra odkrytá $\mathrm{v}$ roce 1985 se nacházela $\mathrm{v}$ hnědošedém hlinitopísčitém zásypu bez archeologického materiálu, malty či stop ekoartefaktů, jenž se podobal výplni řady kapes a vhloubenin v rostlém skalnatém podloží. Na základě analýzy DNA šlo o jedince mužského pohlaví s maximálním stářím jeden týden. Datování nálezu vyplývá ze zjištěné stratigrafie včetně revizního výzkumu v roce 2009 a dendrochronologického data zařazujícího stavbu dnes stojící věže horního hradu až do doby po roce 1307. To naznačuje také, jak ukážeme dále, složitější vývoj v I. stavební fázi (Měřínský 2011a, 224, 228-231; 2014, 475). Nová detailní stratigrafická pozorování spolu se zjištěným dendrochronologickým datem lešeňového trámu vpravo od vstupu do věže určujícím poražení stromu v roce 1307 naznačuje složitější stavební vývoj hradu v jeho nejstarší fázi. Prvou stavební fázi tak lze rozdělit na dva časové úseky IA a IB. V počátečním úseku - kdy bylo sídlo založeno - rámcově vročeném do poslední čtvrtiny 13. až začátku 14. století (prvně zmíněno 1289; srov. výše), kam náleží i uložení dítěte, byla vystavěna prvotní obvodová hradba a k ní se, jak plyne z náznaků substrukce zjištěné při revizním výzkumu v roce 2009 ve východní části skalní rozsedliny, přimykal v místě dnešní hranolové věže patrně věžovitý objekt, který mohl mít ve vyšších patrech i dřevohliněnou konstrukci. S touto fází souvisí s největší pravděpodobností i cisterna, zemnice a suterén větší budovy s nadzemní částí ze dřeva či dřeva a hlíny, jež podle několika maltových úprav podlahy existovala zř́ejmě i ve fázi IB. Po roce 1307 byla na místě staršího věžovitého objektu postavena dodnes stojící (tehdy o jedno patro nižší) hranolová věž a novou obvodní hradbu posunuli více $\mathrm{k}$ jihu (fáze IB rámcově 1310-1350; Měřínský 2011a, 224-225; 2014, 474-475).

V prvé fázi (IA-B) představoval Rokštejn celkem prostou dvojdílnou dispozici. Hlavním prvkem prvotního jádra $(21 \times 19 \mathrm{~m})$ z poslední čtvrtiny 13 . století až počátku 14 . století tedy byla poloobytná věž o rozměrech základny $6,5 \times 6,6 \mathrm{~m}$. Jádro ohraničovala hradební zed’ se zaoblenými rohy, k jejímuž jižnímu průběhu byla zevnitř přiložena zmíněná hranolová věž (Měřínský 2011a, 224, 226). Na ploše severně od věže se nacházely ještě zemnice zasekané do skalnatého podloží a v severní části cisterna. Západně od věže byl dislokován onen suterén rozsáhlého stavení o rozměrech $9,5 \times 4,5 \mathrm{~m}$ s několika maltovými podlahami. Delší západní stěnou se přimykalo k ohradní zdi a spolu s věží funkčně suplovalo zděný palác, který z této stavební etapy 
neznáme. Věž fáze IB měla obytnou i útočištnou funkci. Obytné bylo druhé patro s interiérem o rozměrech $2,37 \times 2,4 \mathrm{~m}$, z jihu je osvětlovalo velké okno a vytápění zajištoval krb. Bránu do horního hradu můžeme v této fázi předpokládat na východě a přes $7 \mathrm{~m}$ široký př́kop vytesaný ve skále kolem něho k ní stoupal dřevěný šikmý most opřený o kůlovou konstrukci. Část plochy pozdějšího dolního hradu zabíralo předhradí podkovovitého tvaru opevněné $1,8 \mathrm{~m}$ silnou hradbou. V této stavební etapě představuje Rokštejn př́íklad sídla nepříliš významného šlechtického rodu z konce 13. až první poloviny 14. věku (Měřínský 1988, 242-243; 1991a, 415-417; 1994, 97; 2007, 57-65; 2011, 41; 2014, 475; Měřínský-Zumpfe 2002, 9-11, 17; Měřínský-Plaček 1989, 17-20; 2010-2011, 126; Měřínský-Plaček-Vlach 2009, 19-20).

Kolem roku 1360, či spíše brzy po roce 1350, kdy hrad nejasným způsobem získal Jan Jindřich (1322-1375, hrabě tyrolský a vévoda korutanský 1335-1341, markrabě moravský 1349/1350), došlo k rozsáhlé přestavbě celého objektu tak, aby vyhovoval potřebám markraběte. ${ }^{1}$ Tuto druhou stavební etapu (fáze II) lze rámcově vymezit dobou po roce 1350 až koncem 14. století, kdy hrad držel Jan Jindřich a jeho synové. $Z$ původního hradu zůstala v podstatě pouze věž horního hradu a úseky obvodové hradby na jižní a částečně též západní i východní straně (fáze IB). Vše ostatní bylo strženo a vybudováno znovu, jen místy s využitím starších základů. Severně od věže byl v horním hradě na ploše $24,5 \times 31 \mathrm{~m}$ zbudován původně jednopatrový plochostropý palác o půdoryse $10,5 \times 23 \mathrm{~m}$. Obsahoval klenebními pasy propojený suterén, zvýšené př́izemí se třemi místnostmi a první patro s velkým reprezentačním sálem na východě a západní místností, kde byla podle sanktuáře umístěna i domácí kaple (obr. 4). Věž byla patrně zvýšena o patro se dvěma okny k západu a východu. Brána v drobné, dovnitř otevřené věži se nacházela na východě poblíž hlavní věže. Její počátky nelze vyloučit již ve fázi IB. Přístup k bráně byl veden od severu podél východního průčelí paláce stoupajícím přihrádkem přímo od nové severní brány do předhradí. Také starou hradbu předhradí strhli a novou zalamující se hradební zdí ze tří stran zformovali dolní hrad. Do hradby byla na východě vetknuta druhá hranolová věž o rozměrech $6,4 \times 6,4 \mathrm{~m}$. Největším objektem dolního hradu, jenž včetně zvlášt' vyděleného horního hradu zaujímal trojúhelnou plochu o základně $60 \mathrm{~m}$ a výšce $74 \mathrm{~m}$, se stal tzv. dolní palác o velikosti $27,5 \times 10,5 \mathrm{~m}$, přistavěný k obvodové hradbě na jihozápadě. Kromě připojeného suterénu měl zvýšené prrízemí a další dvě podlaží, každé o třech místnostech (obr. 5). Jiná rozsáhlá nejméně jednopatrová budova s vnějšími rozměry zhruba $11,5 \times 21$ m (včetně ohradní zdi tvořící stěny stavby na severu a východě) byla vestavěna do severovýchodního nároží dolního hradu. Do jejího suterénu se vcházelo od jihu vchodem v prodloužené ose západní zdi budovy přisazené k severní stěně věže.

Oba paláce hradu měly plochostropé etáže se záklopovými podbíjenými stropy. Reprezentační prostory v nižších patrech byly vybaveny podlahami s reliéfní dlažbou, vyšší patra měla patrně povalové stropy s mazanicovými výmazy. Stěny místností byly hladce omítnuty a pročleněny výklenky. Patrně valbové střechy měly prejzovou krytinu. V horním paláci jsou v západní stěně dochovány v př́izemí a prvém patře dva arkýřové prevety a podobné lze na základě archeologického výzkumu západního parkánu předpokládat i v západní (zřícené) stěně dolního paláce. $\mathrm{Na}$ hradě se v tomto období setkáváme se třemi druhy otopných zařízení - krby, kachlovými kamny sestavenými z nádobkovitých kachlů (dolní palác, některá místnost či místnosti horního paláce) a kamny vystavěnými z komorových polévaných kachlů malého formátu a prořezávaných glazovaných kachlů v reprezentační části horního paláce. Do suterénu a přízemí dolního

\footnotetext{
$1 \mathrm{~V}$ poslední době bylo publikováno na základě dendrochronologických dat zjištěných ve zdivu zejména horního i dolního paláce, že vyrovnávací fošna s malým počtem letokruhů z dolního paláce měla být zhotovena ze stromu pokáceného na přelomu let 1336/1337 a trámek uchycení dveří z horního paláce by měl pocházet ze stromu smýceného v letech 1339/1340. V horním paláci byly datovány další tři konstrukční dřevěné prvky bez zachování podkorních letokruhů a podle analyzátora je datace posledního dochovaného letokruhu ne starši než rok 1339 . $Z$ toho autoři studie o stavebně historickém vývoji hradu (Šabatová-Soukup-Kyncl 2009, 204) vyvodili, že přestavbu hradu zahájil nikoliv markrabě Jan Jindřich, ale již Střižovci alias Hrutovci. Autoři si neuvědomují daleko širší souvislosti, ani skutečnost, že dendrochronologická data představuji terminus post quem, a nelze je využít pro přesné datování. Navíc ani ekonomická situace rodu vlastnícího tři vesnice neumožňovala takto velkoryse koncipovanou přestavbu rodového sídla. K diskusi může být pouze možnost zahájení přestavby markrabětem Karlem, ale ten se o hradě nezmiňuje, což lze považovat za podstatné. Trojicí autorů uváděná lokalizace hradu v místě, kudy procházela lukrativní cesta k Jihlavě, jež měla přinášet profit rodu Hrutovců (srov. výše Vohryzek 2012), je naprostý nesmysl, nebot' ta sice v jedné z větví vedla přes Brtnici (srov. např. Měŕínský 1988a, 55-57, 65; 1988b, 15-18, 29-31,36,38), ale v žádném případě neprocházela údolím říčky Brtnice kolem Rokštejna (srov. Šabatová-Soukup-Kyncl 2009, 204).
} 


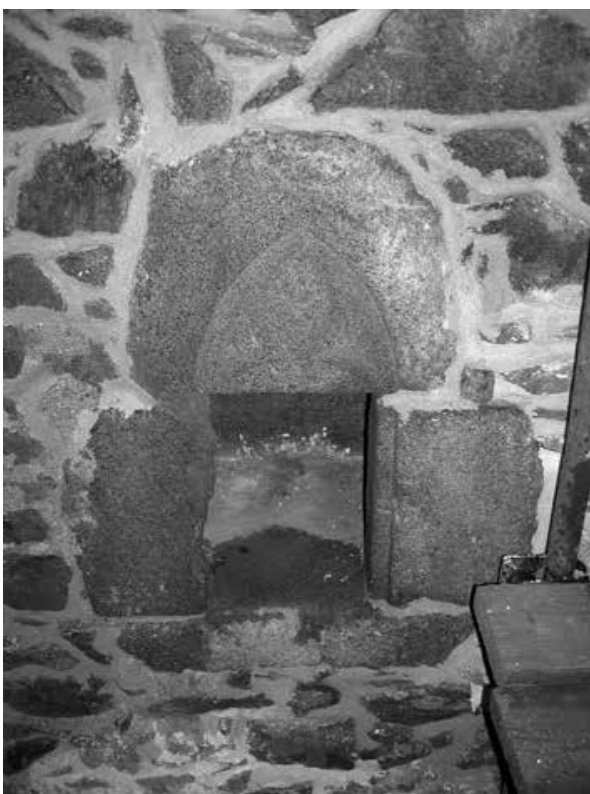

Obr. 4. Rokštejn, k. ú. Panská Lhota, město Brtnice. Výklenek sanktuáře po spárování. Foto L. Kundera.

Abb. 4. Rokštejn, Katastergebiet Panská Lhota, Stadt Brtnice. Nische des Sanktuariums nach Ausfugung. Foto L. Kundera. paláce patrně již za valdštejnských dostaveb po roce 1400 dodatečně vestavěli teplovzdušné topení (Měřínský-Plaček 1989, 20-22; Měřínský 2007, 66-73; Měřínský-Plaček-Vlach 2009, 21-22).

Produktem přestavby Jana Jindřicha byla dispozice, z níž drobnou úpravou za Valdštejnů mohl vzniknout tzv. dvojhrad, a celek doplňoval a spojoval ještě parkán, který se na severu rozšiřoval v opevněné předhradí, $\mathrm{z}$ něhož se branou uprostřed severní hradby vjíždělo do vlastního hradu. Záchranný výzkum $\mathrm{v}$ roce 2012 pod cestou kolem východní strany hradu neprokázal úplný průjezd parkánem, tzn. př́istup jak od Přímělkova, tak Panské Lhoty. Došlo též k vyrovnání plochy nádvoří a byl zasypán i prŕíkop z konce 13. století kolem jádra původního hradu. Na zásypu, v prostoru jihovýchodně od jádra horního hradu, jihozápadním nárožím kontaktně nasedajíc na dolní palác, byla dislokována hradní kuchyně, srubová stavba o rozměrech $6 \times 6,5 \mathrm{~m}$ s kamennou pecí v severovýchodním a starší chlebovou v jihozápadním koutu objektu. Po ukončení markraběcí přestavby, která na základě analýzy všech pramenů a zjištění zapo-

čala mezi roky 1350 a 1360 a skončila nejpozději do roku 1380, vyrostla v údolí Brtnice mohutná hradní stavba s trojnásobným opevněním o celkové zastavěné ploše téměř 0,6 ha (dále srov. Měřínský 1988, 244; 1991, 65-68; 1991a, 418-419; 1994, 97-98; 2007, 73-123; 2011, 43-45; 2014, 478; Měřínský-Zumpfe 2002, 13-14, 18; Měřínský-Plaček 1989, 22-32; 2010-2011, 127-128; Měŕínský-Plaček-Vlach 2009, 22).

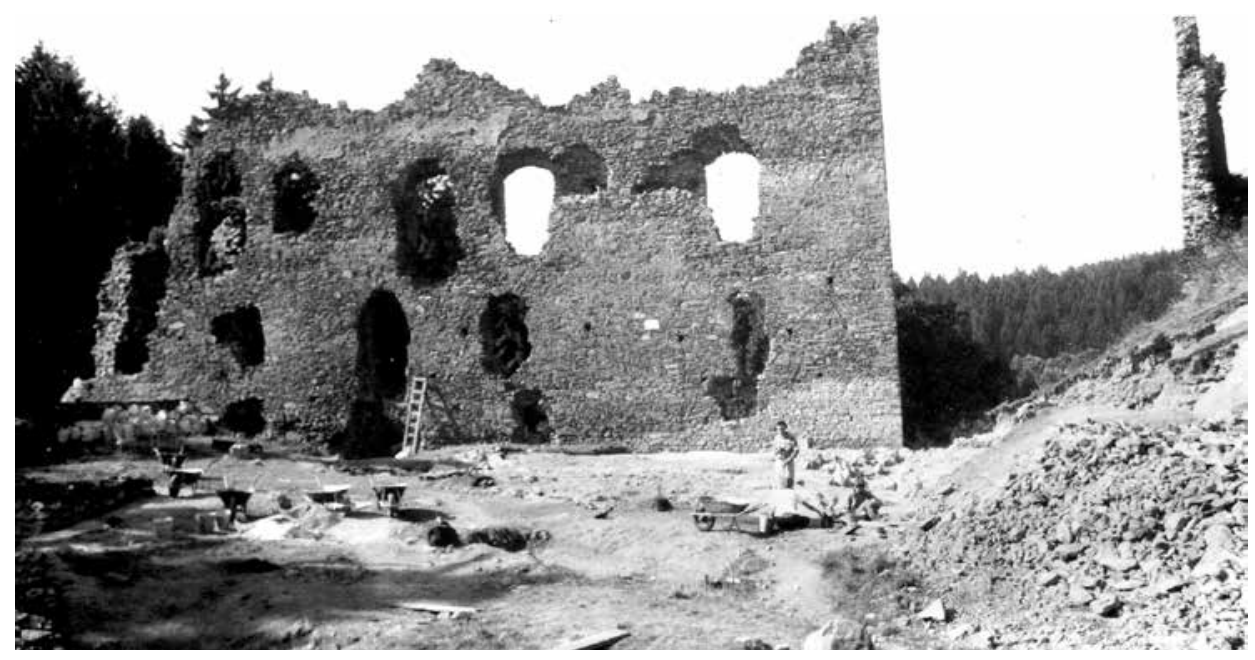

Obr. 5. Rokštejn, k. ú. Panská Lhota, město Brtnice. Východní nádvorní průčelí dolního paláce v roce 1983. Foto M. Plaček. Abb. 5. Rokštejn, Katastergebiet Panská Lhota, Stadt Brtnice. Östliche Hoffassade des unteren Palas im Jahr 1983. Foto M. Plaček. 
Třetí, valdštejnskou etapu (fáze III) stavební činnosti na Rokštejně po roce 1400 charakterizují pouze dostavby, které rozšiřovaly obytné a provozní prostory. V zájmu zvětšení obytné plochy zvýšili palác horního hradu o další patro, i když nelze vyloučit, že vzhledem ke složitosti situace korun zdiva a dodatečnému plentování proběhla již koncem markraběcího období. Dolní palác tehdy vybavili teplovzdušným topením a k jihovýchodní hradební zdi dolního hradu mezi dolní palác a dolní věž přistavěli nový hospodářský trakt, $v$ jehož prvé místnosti se nacházel špýchar na obilí. Další budovu přisazenou k severní stěně dolní věže mezi ni a stavení v severovýchodním koutu ohradní zdi jsme již zmínili. Zvýšena byla také hradba horního hradu a není vyloučeno, že na hradě probíhaly i nějaké dostavby, zejména $v$ té části, která nebyla dosud archeologicky zkoumána. Právě na počátku 15. století, kdy zde sídlil kromě Hynka z Valdštejna i manžel jeho dcery Markéty Zikmund z Křižanova, nabyl Rokštejn charakter dvojhradu (v Čechách snad Choustník, na Moravě byly rozděleny Lelekovice a v určitém období Mikulov) a každá z rodin sídlila v jedné části - horním a dolním hradu (Měřínský-Plaček 1989, 23-24; 20102011, 127; Měřínský 1994, 97-100; 2007, 75-78; 2014, 478; Měřínský-Plaček-Vlach 2009, 22).

Dosavadních třiatřicet výzkumných sezón na hradě Rokštejně přineslo obrovské množství památek středověké hmotné kultury. $Z$ archeologických nálezů je to zejména keramika, jejíž značnou část představuje keramika stavební - cihly, prejzy, dále kamnářské výrobky a technická keramika -, a potom především železné předměty. Nejvíce jsou zastoupena stavební kování, dále militaria, výrobky z barevných kovů, také skleněné, kostěné, dřevěné a kamenné artefakty, doklady uměleckého řemesla, numismatický materiál, ale i množství takových nálezů, jako jsou zvířecí kosti, rybí šupiny, ulity hlemýžd’ů, antropologické doklady, uhlíky i další rostlinné pozůstatky patřící do rámce environmentální archeologie (Měřínský 1988, 246; 1991, 70-75; 1991a, 420-425; 1994, 100-104; 2007, 86-123; 2011, 43-45; 2014, 479; Měŕínský-Zumpfe 2002, 1112, 18; Měřínský-Plaček 1989, 23-24; 2010-2011, 127; Měřínský-Plaček-Vlach 2009, 22-23). Komplexní zpracování těchto nálezů i jejich detailní analýzy přispívají k upřesnění chronologie, poznání reálií života na hradě, skladby stravy, fyzického stavu a vzhledu populace, rostlinného pokryvu v okolí i druhů pěstovaných rostlin, tedy k získání obrazu o ekologii mikroregionu ve středověku, skladbě a charakteru pěstovaných domácích zvířat, živočichů získávaných lovem atd.

Takto pojaté studium se neobejde ani bez spolupráce s řadou př́rodovědných a technických disciplín, z nichž jmenujme např́klad geofyzikální prospekci, metalografické analýzy, petrografii ad. Spolupráce s těmito obory a dalšími oblastmi historických věd pomáhá vytvářet co nejkomplexnější obraz o lokalitě a životě na ní, včetně širších souvislostí s historickými událostmi v oblasti jihozápadní Moravy i v kontextu dějin středověké Moravy vůbec (z dílčích studií uvádíme např. Kühn 1977; Ustohal 2003; Ustohal-Stránský 1993; Měřínský 2003; MěřínskýZumpfe 1994; 1996). Zmínit je nutno také řadu nepublikovaných seminárních, bakalářských a magisterských diplomových prací i doktorských disertací týkajících se i širšího zemědělského zázemí lokality, tj. především zaniklých středověkých vesnic na brtnickém panství a sídel nižší šlechty v okolí (seznam vybraných pramenů a literatury nap̌r. Měřínský 2007, 136-142; 2011, 45; 2014, 479; Měřínský-Zumpfe 2002, 14). Z vnitřní části hradu (již jen dolního) zbývá prozkoumat zhruba 25 čtverců $5 \times 5 \mathrm{~m}, \mathrm{tj} .650 \mathrm{~m}^{2}$, a hlavním úkolem pro následující sezóny je dokončení průzkumu prostoru mezi dolním palácem a horním hradem a západního parkánu. Neuzavřeno zůstává komunikační schéma hradu a přístupové komunikace, sondážemi je nutno ověřit situaci jižního, jihovýchodního až východního parkánu a obléhatelských stanovišt' na zlomu svahu jihozápadně od hradu (Měřínský 2011, 45; 2014, 479; srov. Mazáčková 2011).

Vzhledem k uchování zř́iceniny $\mathrm{v}$ hmotě zdiva až do druhých pater paláců a k podstatnému zvýšení úrovně poznání dispozice, významu a stavebního vývoje hradu došlo k mimořádnému posílení postavení lokality v hierarchii kulturních památek nadregionální důležitosti. Význam lokality v kontextu národních dějin, a v jejich širších středoevropských souvislostech (včetně vývoje architektury), si vynutil její památkovou obnovu a revitalizaci. A to nejen kvůli ochraně a uchování kulturního dědictví minulosti, regionálních kulturních aktivit a tradic, ale i pro rozvoj turistického ruchu, kdy to vynucuje i sám návštěvnický provoz. Perspektivně se počítá s vy- 
užitím areálu hradu, situovaného navíc v romantickém údolí dolního toku Brtnice, ke kulturním a osvětovým účelům i s prezentací výsledků výzkumu. Za tímto účelem byl v letech 2000-2002 z podnětu tehdejšího OÚ a pozdějšího MÚ Brtnice a starosty obce Ing. J. Přibyla a za konzultací a přispění odboru Památkové inspekce MK ČR v Praze zastoupeného JUDr. Jiřím Varhaníkem projekční firmou vypracován projekt „Konzervace a stabilizace konstrukcí hradu Rokštejn“. Jeho realizace začala $\mathrm{v}$ roce 2003 a jako poradce byl doporučen a technického dozoru se ujal Ing. Jan Vinař (Měřínský-Plaček 2010-2011, zvl. 128-130).

Obsahem projektu je konzervace nadpovrchových i výzkumem odkrytých zdiv, zavedení určitého návštěvnického režimu na lokalitě a také její využití ke kulturním účelům i prezentaci. Kromě předpokládané expozice v Brtnici či Panské Lhotě je zamýšlena i malá expozice dějin a stavebního vývoje přímo na hradě (např. v zastř̌ešené a zpřístupněné horní věži). Návštěvníkům je možno prezentovat i každoročně probíhající archeologický výzkum. Areál hradu může být po dokončení konzervačních a stabilizačních prací využíván i k dalším kulturním aktivitám, jako jsou koncerty, divadlo apod. (Měřínský 2007, 134; 2014, 479-480; Měřínský-Plaček 20102011, zvl. 128-130; Měřínský-Plaček-Vlach 2009, 23-28). Projekt „Brány Rokštejna 2014“ vypracovaný v grantovém programu Norských fondů Ing. J. Vinařem a Ing. P. Babínkem v rámci projekce MURUS, monumenta renovamus, spol.s r. o., však bohužel nebyl přijat.

Koncepce záchrany maximálně vychází ze současných trendů památkové péče, ale přihlíží též k efektivnosti vynaložených nákladů. Očekává realizaci bez jakékoliv nadbytečné velkorysosti a způsob úprav je zcela podřízen uchování historické autenticity a atmosféry zrríceniny při současném zastavení procesů jejího postupného rozpadu. Proto jde především o citlivou konzervaci, tzn. stabilizaci ohrožených nadzemních konstrukcí a zdiv odkrytých činností archeologů, tedy i o prezentaci ploch prozkoumaných při archeologickém výzkumu. Záchranu zrríceniny hradu Rokštejna komplikuje jeho torzální stav a nutnost zabezpečení vysokého zdiva (obr. 6). Poněkud odlišné jsou požadavky na ochranu archeologických památek, jež byly v areálu odkryty (např. jejich zvýraznění). Specifika tohoto druhu památek vyžadují nejen citlivý, ale i osobitý př́stup ke každému objektu, který musí respektovat „cenu stáříi“ ve smyslu úvah A. Riegla a $\mathrm{M}$. Dvořáka. $Z$ technických úprav je nutné odvést srážkové vody, zejména $\mathrm{z}$ rozlehlých ploch a z drenáží zdiva, usměrnit pohyb návštěvníků a zamezit vstupu ze všech stran (Měřínský-Plaček 2010-2011, 128).

J. Vinař stanovil a usměrňuje pracovní postupy, určuje jejich pořadí a upravuje technická řešení podle skutečností nově zjištěných prri zajištovacích pracích (Vinař 2011; srov. Měřínský-

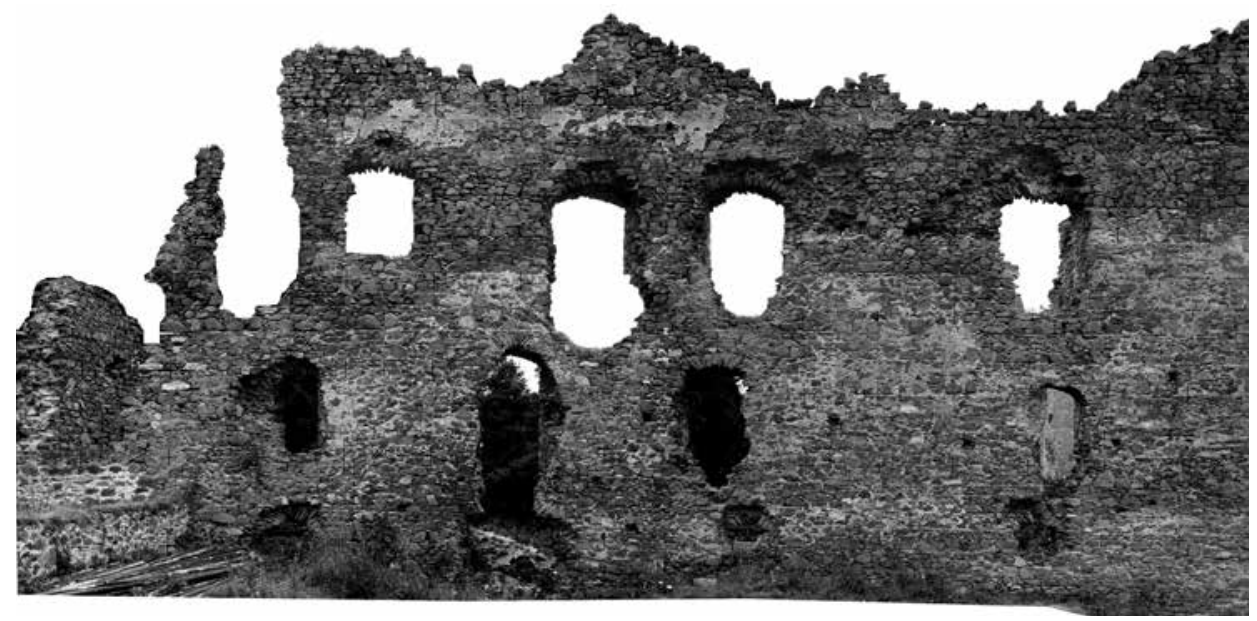

Obr. 6. Rokštejn, k. ú. Panská Lhota, město Brtnice. Východní nádvorní průčelí dolního paláce v roce 2003. Fotogrammetrie J. Pavelka, 2003.

Abb. 6. Rokštejn, Katastergebiet Panská Lhota, Stadt Brtnice. Östliche Hoffassade des unteren Palas im Jahr 2003. Photogrammetrie J. Pavelka, 2003. 
Plaček 2010-2011, 128-129). Jako cíle opravy a konzervace zříceniny hradu Rokštejna stanovil zachování a konzervaci autentických konstrukcí a detailů, zajištění stability všech částí stavby, ochranu objektu včetně jeho detailů, fixaci zdiv zjištěných při archeologickém výzkumu, úpravy k zajištění návštěvnického provozu a minimalizaci veškerých zásahů. Nejdůležitější technologie používaná při konzervaci, stabilizaci i pro ochranu konstrukcí a prvků je oprava a doplňování zdiva (obr. 7). Uplatňuje se hloubkové spárování zdiva a trhlin, pouze u silného narušení nebo deformací se užívají ochranné a stabilizační přizdívky. Speciální technologie, jako je tlaková injektáž, se použily pouze výjimečně pro zajištění trhlin ve zdivu věže horního hradu (Vinař 2011, 51).

Je nutno zdůraznit, že konzervaci zdiv na zřícenině neprovádí podnik specializovaný na zajištění památek, ale místní stavební firma, jejíž pracovníci brzy zvládli navržené technologie

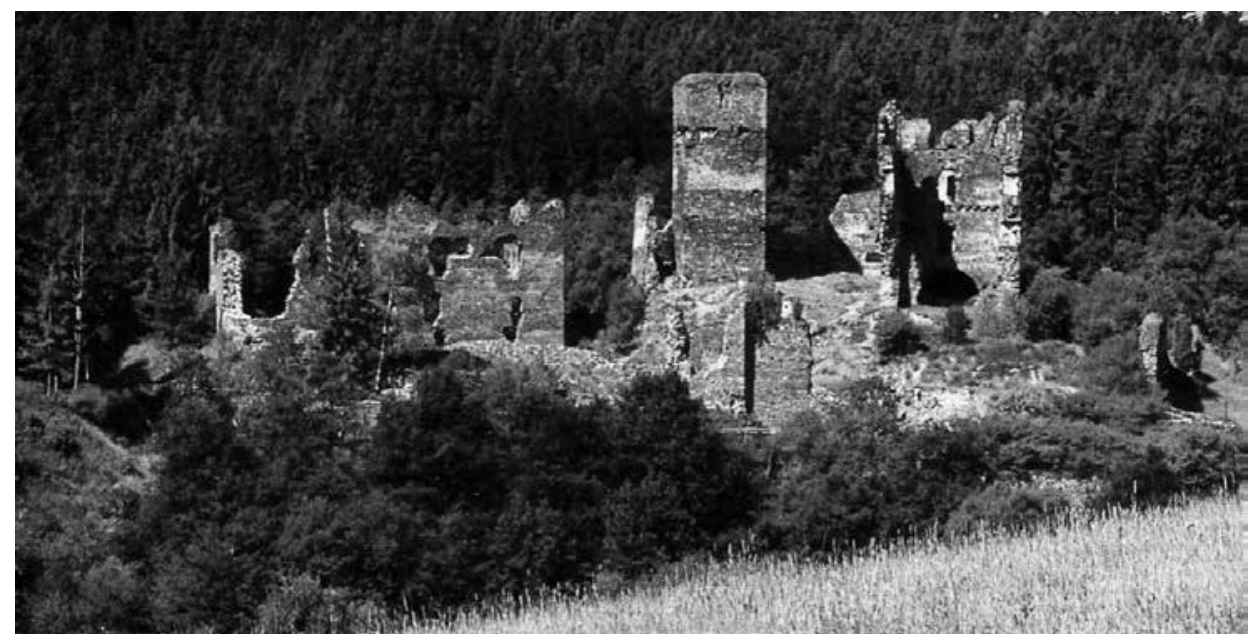

Obr. 7. Rokštejn, k. ú. Panská Lhota, město Brtnice. Celkový pohled na zříceninu od východu. Stav na počátku 90 . let minulého století. Podle pohlednice foto J. Kasal.

Abb. 7. Rokštejn, Katastergebiet Panská Lhota, Stadt Brtnice. Gesamtansicht der Burgruine von Osten. Zustand zu Beginn der neunziger Jahre des vergangenen Jahrhunderts. Nach einer Ansichtskarte, Foto J. Kasal.

a v dosavadním průběhu realizace je dodržují. Důležité je, že po celou dobu vykonávají stavební práce stejní pracovníci. Z toho vyplývá, že př́iklad revitalizace zříceniny hradu Rokštejna potvrzuje podstatný význam znalosti řemeslných praktik tradičních stavebních technik pro úspěšnou konzervaci památky (obr. 8). Rozhodující je zdění z lomového kamene, které je vždy nutno přizpůsobit lokálním stavebním materiálům. Charakter lomového zdiva se velmi liší podle druhu horniny, její štěpnosti, velikosti kamene a jeho formy. Část má tvořit sbíraný kámen (Měřínský 2007, 123). U každého druhu kamene se musí zedník zdění lomového zdiva znovu učit a přitom dodržovat několik principů, jež se u historického zdiva $\mathrm{z}$ lomového kamene uplatňovaly, což zde nelze podrobně popisovat. Podle velikosti kamene se zdilo ve vrstvách o výšce $60-80 \mathrm{~cm}$, spodní řádky vrstvy se zakládaly z větších kamenů s co nejrovnější lícovou stranou položených do silné vrstvy malty a u vrstevnatého kamene vždy s vodorovnými štěpnými plochami. Přitom jádro zdi bylo vyskládáno z menších nerovných kamenů zatloukaných do ložné vrstvy malty, muselo se dbát na provázání kamene a líc byl dorovnáván menšími kameny v celé délce zdi. Do ložných spár se nanáši jen tolik malty, aby vyplnila mezery, a přebytečnou maltu pak strhne hrana lžíce, přičemž dříve se roztírala do líce (Vinař 2011, 51).

Při opravách zdiva je nutno dodržovat následující zásady. U dozdívek navazovat na řádky původního zdiva - na rozdíl od historického zdiva se při konzervaci lomové zdivo neomítá, zůstává režné, ač na Rokštejně máme i stopy vnějších omítek. Proto je potřeba zdivo dodatečně vy- 


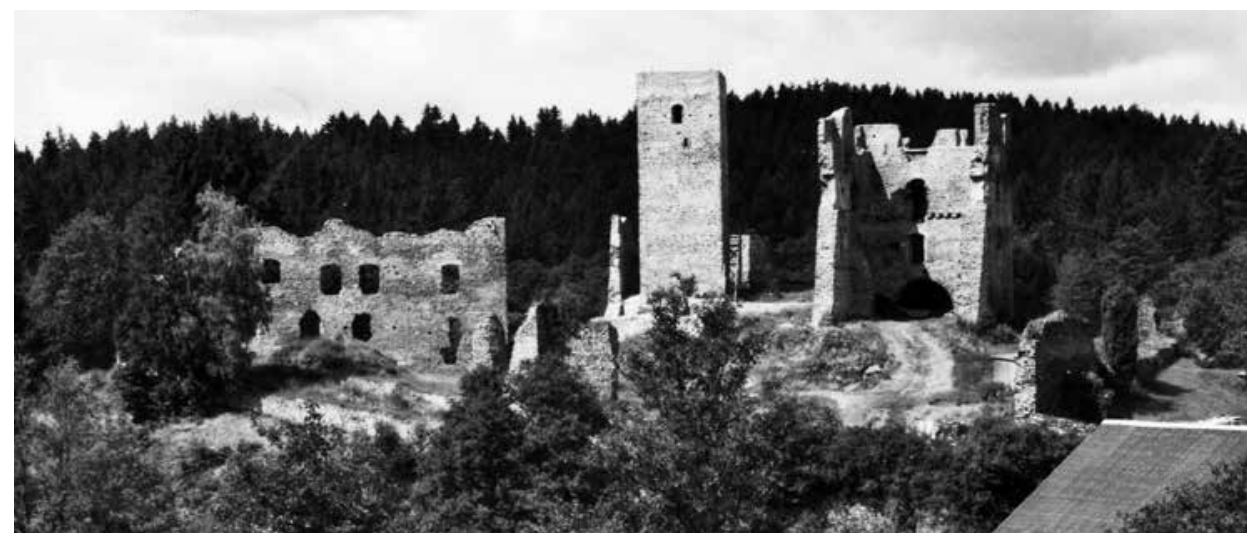

Obr. 8. Rokštejn, k. ú. Panská Lhota, město Brtnice. Pohled na věž a palác horního hradu a palác dolního hradu od východu po provedení většiny zabezpečovacích v roce 2012 . Foto $M$. Plaček.

Abb. 8. Rokštejn, Katastergebiet Panská Lhota, Stadt Brtnice. Blick auf den Turm und Palas der oberen Burg und auf den Palas der unteren Burg im Jahr 2012 nachdem die meisten Sicherungsarbeiten abgeschlossen waren. Foto M. Plaček.

spárovat. Z těchto důvodů je nutno provádět tyto práce co nejdříve po vyzdění, aby se spárovací malta dobře spojila s maltou ve zdivu. Vzhled spárování je přizpůsoben okolnímu zdivu, tedy se při opravě může spárovat až k líci zdiva, nebo za líc kamenů. K těmto konzervačním pracím je používána malta nastavená cementem, přičemž důležité je složení písku. Ten by měl mít plynulou zrnitost a obsahovat také větší zrna. Je žádoucí, aby se zrnitostí i barvou malta podobala vzhledu původního pojiva, přičemž př́isada hydraulického pojiva je nutná, aby se dosáhlo počáteční pevnosti malty zabraňující vyluhování vápna srážkovou či vzlínavou vodou. Při opravě korun se zachované původní zdivo většinou chrání jednou vrstvou kamene, přezdí se rozvolněný povrch a tvar koruny se upraví do formy umožňující dobré stékání vody. Pro ochranu širších korun se u masivnějšího opevnění dolního hradu uplatnilo drnování, u vysokých a tenčích zdí dolního i horního paláce pak ochrana olověným plechem kotveným pomocí měděných pásků. U způsobu upevnění a v tloušt'ce plechu došlo ke změně poté, co kryt korun zdiva dolního paláce poškodila vichřice (Vinař 2011, 51, 55, 57, 59).

Vyšší partie zdiva jsou po zpřístupnění z lešení podrobeny stavebně historickému průzkumu s podrobnou dokumentací i interpretací zachovaných konstrukcí i jejich detailů tak, aby při spárování a dozdívkách nezanikly či nebyly znejasněny autentické situace. U paláce horního hradu a věže bylo zpracováno několik variant zastřešení a po diskusi zvítězilo řešení respektující požadavky orgánů památkové péče na způsob takového uplatnění nových konstrukcí, které by nenarušily vnější pohledy na hradní zříceninu a její charakter. Uvnitř horního paláce došlo ke zřízení stř́šky kryté plechem, jež částečně chrání omítky a architektonické prvky interiéru (obr. 9). Naopak v prŕípadě věže dostalo přednost zvýšení koruny o subtilní parapetní zed' z kamene před jejím zadrnováním a zřízením kovového zábradlí vyhlídkové plošiny. Její terasa je kryta titanzinkovým plechem, na němž jsou položeny dřevěné pochůzné rošty, a je odvodněna vnitřním svodem a chrličem ve spodním patře věže. Dřevěné vnitřní stropy a schodiště svými konstrukcemi využívají původní kapsy ve zdivu a také vnější př́stupové schodiště vychází z místa, kde jeho polohu zachytil archeologický výzkum (Vinař 2011, 57, 59).

Stabilizační dozdívky se omezily na staticky nezbytnou míru, přičemž tam, kde bylo nutné zhotovit novotvar, volil se $\mathrm{k}$ jeho vytvoření materiál odlišný od původního zdiva, jako např́iklad cihly či cihly opatřené tenkou vrstvou omítky. Vlastní dozdívky mají větší rozsah v těch místech, kde je třeba zajistit bezpečnost návštěvníků, např. v místech, kde mají funkci parapetu či zábradlí. Do větší výšky jsou vyzdívány také hradební zdi, jež budou tvořit ohrazení celého areálu. Dozdívky chránící nebo fixující zbytky zdiv zjištěných archeologickým výzkumem se tam, kde budou tyto objevené konstrukce prezentovány, vyzdívají nad budoucí upravený terén. 


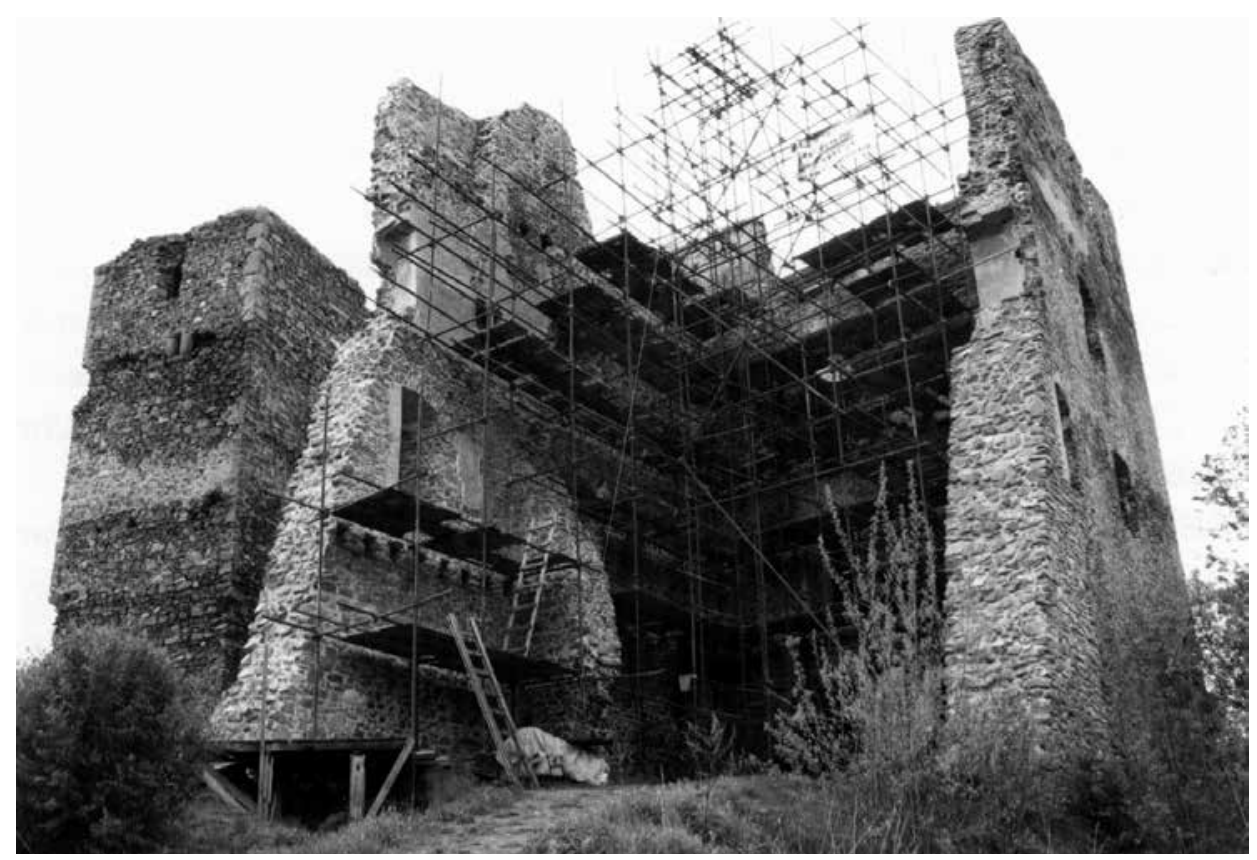

Obr. 9. Rokštejn, k. ú. Panská Lhota, město Brtnice. Horní palác a věž v letech 2005-2007 od východu při restauraci a stabilizaci zdiv. Foto S. Jirků.

Abb. 9. Rokštejn, Katastergebiet Panská Lhota, Stadt Brtnice. Oberer Palas und Turm in den Jahren 2005-2007 von Osten während der Restaurierung und den Stabilisierungsarbeiten am Mauerwerk. Foto S. Jirků.

Realizační dokumentace má většinou formu zákresů do fotoplánů, někde fotografí́ či pracovních skic provedených na místě. Pro úspěšnou realizaci konzervačních prací je nezbytný pravidelný dohled projektanta, stavebního a památkového dozoru, když se zasahuje do terénu, také archeologa (Vinař 2011, 59).

Při probíhajícím památkovém zabezpečení se provádí stabilizace a fixace hmot vertikálních konstrukcí statickými metodami, ale výhradně u ohrožených konstrukcí s využitím opticky minimálně rušivých prvků. Šlo hlavně o východní části severní a jižní stěny horního paláce. Vzhledem ke kvalitnímu provázání severní zdi se stabilní západní zdí byl problém vyřešen fixací horní ohrožené partie skrytým ocelovým táhlem podél příčky. Menší trhliny jsou stahovány profily tenkých kotev Helifix. V podélném směru byla vyklínováním zachycena odklánějící se východní část jižní zdi (Měřínský-Plaček 2010-2011, 129).

Konsolidace narušeného zdiva a doplnění narušených líců se provádí výplní kaveren novým zdivem, jen podle potřeby hloubkovým doplněním malty ložných spár, výjimečně s vyklínováním prasklin. Důležité jsou boční lomové plochy, kde byl dodržen charakter doplňovaného zdiva a jeho vazba. Týká se to hlavně věže horního hradu a rozměrné kaverny v jeho západní hradbě, jejíž otvor byl dříve vyspravován betonem. Již zmíněné rozvolněné koruny zdiva po odstranění zvětralé malty zpevnila její náhrada, prŕípadně přezdění, hlavně u obou paláců, na severní hradbě a obou věžích. Vyrovnávka korun je minimalizována (Měřínský-Plaček 20102011, 129).

Zajištění korun zdí horního paláce proběhlo i s fixací dochovaných omítek interiéru z vnitřního lešení. Mechanicky a chemicky očištěné a vápennou vodou konzervované plochy omítek v západní části horního paláce chrání před deštovou vodou pultové stř́ǐšky umístěné v posledním podlaží na dřevěných polokrokvích. Vazby spočívají na pozednici kotvené na dubových špalcích v bývalých kapsách po trámech a mezi nimi s využitím chemických kotev. Překryta jsou 
také torza několika krbů i jejich sopouchy, aby přes ně nevnikaly do zdiva srážky. Za krytinu posloužil zinkovotitanový patinovaný plech (Měřínský-Plaček 2010-2011, 129).

Zajištění kleneb a pasů se provádělo výhradně tradičními metodami a materiály. Klasické klenby se na Rokštejně nevyskytují, jde pouze o pasy a záklenky oken, z nichž k ojedinělému doklenutí došlo pouze u těch, u nichž máme doklad o prolomení a devastaci v posledních třiceti letech a jejichž absence ohrožovala stabilitu střepů meziokenního zdiva. Jde hlavně o nádvorní průčelí dolního paláce. U dalších ohrožených záklenků v horním paláci a jižním okně věže došlo k vyklínování a zabezpečení jejich rubu. Úpravy a stabilizace odkrytých archeologických objektů se prováděly se snahou o podobnost s původním nadzemním zdivem, přičemž pro pochopení souvislostí došlo u některých zdí k náznakovému vytažení nad terén a zatravnění. Jak již bylo uvedeno, dřevěné konstrukce trámových pater v horní věži zčásti využívají původní kapsy, vnitřní schodiště je provedeno jako samonosné a ke vstupu do patra je také zřízeno venkovní samonosné schodiště (Měřínský-Plaček 2010-2011, 129).

Dozdění obvodových zdí hradu bylo provedeno z tradičního materiálu, v nejnutnějším rozsahu a jen s ohledem na omezení vstupu. Jde o takové dozdívky, aby výška koruny nad venkovním terénem nebyla menší než $2,5 \mathrm{~m}$, a místně parapet nahradí plaňkový plůtek. Při pracích jsou užívány pouze tradiční technologie a materiály (vápno, původní kámen z destrukcí na zřícenině a dále dřevo). Opticky se podařilo potlačit nutné nové doplňky, jen v prvých fázích se opomnělo tónovat nové malty, u nichž bohužel bude nutno vyčkat na přirozenou patinaci. Rovněž se podařilo zabránit nadbytečnému doplňování zdiva a kamenické články se v podstatě, s výjimkou stabilizace přilehlých konstrukcí nalezenými elementy, nevsazovaly (Měřínský-Plaček 2010-2011, 129-130).

Úprava ploch a otevřených prostorů bude přirozená, má respektovat stav z doby před zánikem lokality a přihlížet též $\mathrm{k}$ jejich nutnému odvodnění. Ideální stav je zatravnění s prŕípadnými náznaky stezek, výjimečně bude na extrémně namáhaných pochůzných plochách použita přírodní dlažba. Zeleň se musí regulovat a je nutné zabránit vzniku křovinných zákoutí, kde se drží vlhkost ohrožující zdivo a jeho základy. To však již souvisí s údržbou. Odvodnění musí být přirozené, již proto, že většina ploch má těsně pod povrchem skalní podklad, ale je pro ně možné využít bývalý př́ikop. $Z$ východního svahu jádra hradu a severní části nádvoří dolního hradu bude nutno zhotovit drenáž mimo hradbu dolního hradu v místě vstupu. Plocha horního paláce je přirozeně spádována na severní svah mimo základy (Měřínský-Plaček 2010-2011, 130).

Věcné a časové rozčlenění akcí vedoucích ke konzervaci a úpravy k využití zříceniny hradu Rokštejna vyplývaly především ze stupně ohrožení některých částí lokality, dále z potřeby jeho uzavření před nekontrolovatelným pohybem osob, který bývá spojen s poškozováním až vandalismem, a konečně z potřeb zajištění konstrukcí před rozpadem. $Z$ hlediska rozčlenění akcí na relativně dlouhou dobu, a protože není podrobně znám rozsah a náročnost prací ani finanční pokrytí nároků na tyto činnosti, jsou zajištovány až průběžně podle potřeb a také podle finančních možností města a příspěvků MK ČR. Z potřeb a současné naléhavosti prací víceméně vyplývá pořadí realizovaných činností, které se proto občas měnilo, například v důsledku statického posudku, jenž považoval za zcela akutní ohrožení paláce horního hradu (Měřínský-Plaček 2010-2011, 130). V současnosti zbývá dokončit severní obvodovou hradbu dolního hradu s původním vjezdem do nádvoří a její napojení na severozápadní nároží horního paláce, dále úpravy nově zřízeného vstupu při severovýchodním nároží dolního hradu včetně zafixování zdiva budovy, jež je zde situována, a vyznačení některých základů odkrytých archeologickým výzkumem.

Po dokončení výzkumů a po památkovém zabezpečení hradu Rokštejna se předpokládá jeho sezónní využití k rekreačním, kulturním a poznávacím účelům. Atraktivní jistě bude zastřešená a upravená věž horního hradu, nyní zpř́ístupněná, která poskytne pohled na celý areál a údolí Brtnice před jeho vyústěním do údolí Jihlavy. V archeologické sezóně mohou návštěvníci přímo sledovat i každoročně probíhající výzkumy. O případné, ovšemže citlivé úpravě nádvoří dolního hradu ke koncertům komorní, folkové, trampské hudby, menším divadelním představením a kombinovaným pásmům historického šermu s jinými kulturními produkcemi bude rozhodnuto po ukončení památkového zajištění. Možnosti totiž nabízí i louka pod hradem; v obou 


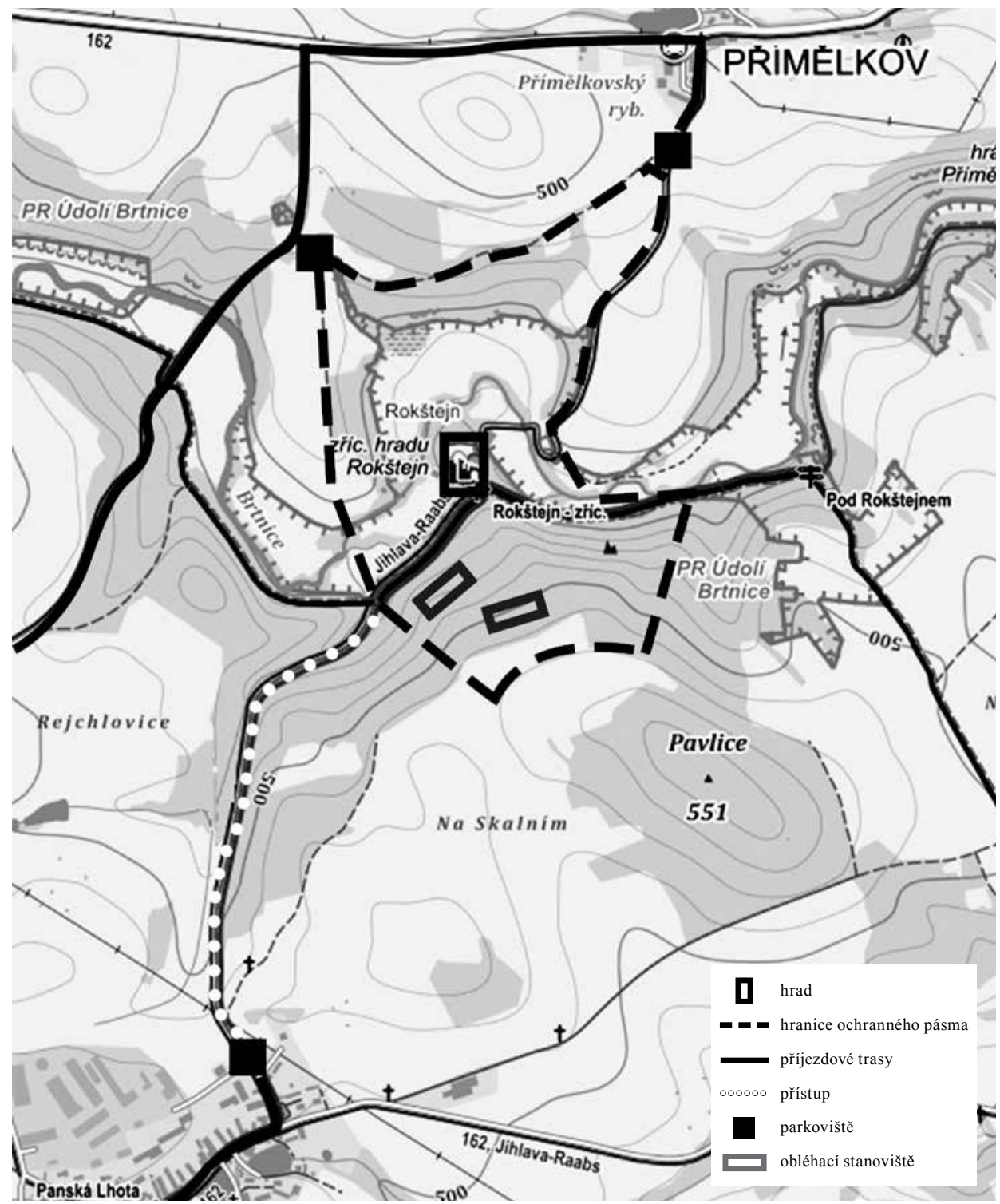

Obr. 10. Rokštejn, k. ú. Panská Lhota, město Brtnice. Situace hradu na základní mapě 1:25 000 s navrženým ochranným pásmem památky. Vyhotovil M. Plaček.

Abb. 10. Rokštejn, Katastergebiet Panská Lhota, Stadt Brtnice. Situation der Burg auf einer Grundkarte im Maßstab 1:25 000 mit geplanter Denkmalschutzzone. Erstellt von M. Plaček.

prŕípadech bude třeba řešit potřeby hygieny. Očekávaný ekonomický výnos by měl pokrýt náklady na sezónní dohled a na základní údržbu (regulace zeleně, údržba stavby).

Z požadavků na ochranu KP Rokštejn též vyšel návrh ochranného pásma, který respektuje i širší zájmy ochrany prŕírody. Proto bylo nutno vytyčit jak pásmo ochrany, tak podmínky pohybu a chování návštěvníků (obr. 10). Předpokládaná zvýšená návštěvnost lokality sama o sobě zatěžuje památku a její přírodní prostředí. Nelze zanedbat také stanovení podmínek pro případné stavby, a to nejen pro dočasné objekty, ale i pro komunikace, sítě, terénní úpravy a pro výsadbu 
stálých porostů. Všechny aspekty musí být projednány s dotčenými orgány samosprávy, státní správy a odborných organizací. Z hlediska ochrany údolí s říčkou Brtnicí a mlýnským náhonem, který podél úpatí ovíjí skalní suk s hradem, a samé pozoruhodné budovy mlýna, je potřebné vytyčit hranici pásma již nad odpojením náhonu (nad jezem) a pod opětným spojením náhonu a Brtnice. Ochranu je nutné poskytnout svahům údolí na všech stranách, což je důležité i pro uchování stavu porostů, které dosud umožňují výrazné pohledové uplatnění hradu v civilizačně nenarušeném prostředí (např. vedením vysokého napětí, silnicí apod.). Proto je do pásma zahrnuta plocha údolních svahů až po jejich horní hranu, a to na východě, severu a západě.

Ochranu si zasluhuje i lesní partie na jihu, v níž je ve spočinku svahu jižně hradu pozůstatek obléhacího opevnění, a alespoň začátek zalesněné plužiny na jihovýchodě. Hranice ochranného pásma v terénu určují sledovatelné jevy - cesty, hranice lesa apod. Tam, kde to není možné, budou umístěny pevné značky. Ochranné pásmo bylo navrženo také s ohledem na dopravu návštěvníků. Kvůli riziku provozu po úzké cestě od Přímělkova je navrženo parkování nad vesnicí a na severu při rozcestí silnice Stř́žžov-Přímělkov a polní cesty. Obě parkoviště jsou dostupná z této silnice, druhé i zpevněnou komunikací z Panské Lhoty. Z parkovišt' vedou cesty a stezky do údolí Brtnice. Možnost parkování je i v Panské Lhotě u místní samoobsluhy a cesta k hradu vede zajímavou úžlabinou potoka. Vyhlášením ochranného pásma dostanou místní orgány do rukou právní nástroj pro ochranu kulturní památky Rokštejn a jejího př́ímého a bezprostředního okolí.

Tato studie je výstupem projektu „Historické využívání krajiny Českomoravské vrchoviny v pravěku a středověku“ Programu aplikovaného výzkumu a vývoje národní kulturní identity NAKI DF13P010VV005.

\section{Literatura}

BRÁNY ROKŠTEJNA, 2014: Brány Rokštejna dokořán, projekce MURUS, s. r. o., Ing. J. Vinař, Ing. P. Babínek, průvodní zpráva. České Budějovice.

KREJSOVÁ, J.-MĚŘÍNSKÝ, Z., 2007: 25. sezóna archeologického výzkumu hradu Rokštejn, k. ú. Panská Lhota, Archeologické výzkumy na Vysočině 1, 2007, 44-46.

KÜHN, F., 1977: Obilí z hradu Rokštejna u Luk nad Jihlavou - Getreide aus der Burg Rokštejn bei Luka nad Jihlavou, PV 1975, 93-94.

MAZÁČKOVÁ, J., 2011: Obléhací postavení u hradu Rokštejna - Belagerungsstellungen bei der Burg Rokštejn, AH 36, 61-85.

MĚŘÍNSKÝ, Z., 1985: Zpráva o výzkumu hradu Rokštejna, k. ú. Brtnice (okr. Jihlava), v roce 1985, 8 s., 35 obr. př́il., Brno, NZ ulož. v archivu AÚ ČSAV Brno, čj. 253/85; dále ulož. Vodorozvoj n. p. Brno, KSSPPOP Brno, MK ČSR Praha.

- 1986: S Jiskrou a Archeologickým ústavem Brno o středověkém osídlení na Jihlavsku. Dějiny a výzkum hradu Rokštejn. Seriál na léto 1-7, Jiskra (Jihlava), 27-68, č. 56-62 z 15., 18., 22., 25., 29. VII., 1. a 5. VIII., vždy s. 5.

- 1988: Archeologický výzkum hradu Rokštejna 1981-1987. Výsledky a perspektivy, VSV VI, 241-250.

- 1988a: Brtnice a její okolí od poloviny 13. století do válek husitských. In: Dějiny Brtnice a připojených obcí (ved. aut. kol. J. Janák), 51-99. Brno - Brtnice.

- 1988b: Počátky osídlení Brtnicka a nejstarší dějiny obce. In: Dějiny Brtnice a připojených obcí (ved. aut. kol. J. Janák), 13-49. Brno - Brtnice.

- 1991: Hrad Rokštejn a jeho úloha v předhusitském a husitském období - Rokštejn Castle and Its Role in the Pre-Hussite and Hussite Periods - Die Burg Rokštejn und ihre Aufgabe in der vorhussitischen und hussitischen Zeit. In: Sborník př́íspěvků k 555. výročí vyhlášení basilejských kompaktát v Jihlavě, 65-82. Brno - Jihlava.

- 1991a: Hrad Rokštejn na Jihlavsku. Deset let archeologického výzkumu - Burg Rokštejn, mittelalterliche Burg im Kreis Jihlava (Iglau). Zehn Jahre der archäologischen Forschung [Mödling 1993], 16 s., zvl. otisk z VVM XLIII, 1991, 413-427.

- 1994: Rokštejn, mittelalterliche Burg im Kreis Jihlava (Iglau). Ergebnisse der archäologischen Forschungen in den Jahren 1981-1992. In: Symposion Die Burgenforschung und ihre Probleme. Ergrabung-Kon- 
servierung-Restaurierung. Symposion in Krems an der Donau vom 3. bis 5. November 1992. Fundberichte aus Österreich. Materialhefte, Reihe A, Heft 2, 97-104. Wien.

- 2003: Olověná plomba se znakem Lucemburků z hradu Rokštejna (k. ú. Panská Lhota, o. Jihlava, Morava) - Bleiplombe mit dem Wappen der Luxemburger aus der Burg Rokštejn (Katastralgebiet Panská Lhota, Bez. Jihlava/Iglau, Mähren). In: Ad vitam et honorem. Profesoru Jaroslavu Mezníkovi přátelé a žáci k pětasedmdesátým narozeninám. K vydání připravili Tomáš Borovský, Libor Jan a Martin Wihoda, 629-637. Brno.

- 2007: Hrad Rokštejn. Dějiny, stavební vývoj a výsledky čtvrtstoletí archeologického výzkumu 19812006. Brtnice - Brno.

- 2011: Hrad Rokštejn (k. ú. Panská Lhota, město Brtnice, Morava). Výsledky archeologického výzkumu 1981-2010 a jeho další perspektivy - Burg Rokštejn (Katastergebiet Panská Lhota, Stadt Brtnice, Mähren). Die Ergebnisse der archäologischen Grabungen aus den Jahren 1981-2010 und ihre künftigen Perspektiven, AH 36, 37-49.

- 2011a: Lidská stavební a ochranná obět’ z hradu Rokštejna. In: Co můj kostel dnes má, nemůže kníže odníti. Věnováno Petru Sommerovi k životnímu jubileu (Doležalová, E.-Meduna, P., edd.), 223-235. Praha.

- 2014: Burg Ruckstein/Rokštejn (Katastergebiet Panská Lhota, Stadt Brtnice/Pirnitz, Mähren), Ergebnisse der archäologischen Forschungen zwischen 1981 und 2010 und die Zukunftsperspektiven. Præhistorica XXXI/2. Acta Instituti archæologici Universitatis Carolinae Pragensis. Tradition - Umgestaltung Innovation. Transformationsprocesse im hohen Mittelalter. Herausgegeben von Eike Gringmuth-Dallmer und Jan Klápště in Zusammenarbeit mit Jan Hasil, 471-481. Univerzita Karlova v Praze.

MĚŘÍNSKÝ, Z.-PLAČEK, M., 1989: Rokštejn, středověký hrad na Jihlavsku (jeho dějiny, stavební vývoj a výsledky archeologického výzkumu 1981-1989) - Burg Rokštejn, mittelalterliche Burg im Kreis Jihlava (Iglau), seine Geschichte, bauliche Entwicklung und Ergebnisse der archäologischen Forschung in den Jahren 1981-1989 - Рокштейн, стредневековой град в области города Йиглава. История, строителъное развитие и резулътаты археологических исследований в 1981-1989 гг. Brno - Brtnice.

- 2010-2011: Hrad Rokštejn - problémy jeho památkového zajištění - Rokštejn Castle - Problems relating to the conservation, Acta Musaei Scepusiensis, 124-135.

MĚŘÍNSKÝ, Z.-PLAČEK, M.-VLACH, R., 2009: Hrad Rokštejn - Rokštejn Castle, Zpravodaj STOP, časopis Společnosti pro technologie ochrany památek 11, č. 4, 17-29.

MĚŘINSKÝ, Z.-ZUMPFE, E., 1994: Keramika z hradu Rokštejna (okr. Jihlava) a její vztahy k jihlavské a dolnorakouské keramice - Keramik aus der Burg Rokštejn (Bez. Jihlava/Iglau) und ihre Beziehungen zur Iglauer und niederösterreichischen Keramik, AH 19, 407-413.

- 1996: Kachle malého formátu z Jihlavy a hradu Rokštejna a jejich ikonografie - Kleinformatige Ofenkacheln aus Iglau (Jihlava) und der Burg Rokštejn (Bez. Jihlava) und ihre Ikonographie, AH 21, 499-503.

- 2002: Rokštejn, stř̌edověký hrad u Panské Lhoty (město Brtnice, Morava). Výsledky archeologických výzkumů v letech 1981-2001 - Rokštejn, mittelalterliche Burg bei Panská Lhota (Stadtgemeinde Brtnice, Mähren). Ergebnisse der archäologischen Forschungen aus den Jahren 1981-2001, AH 27, 9-19.

PLAČEK, M., 1996, ${ }^{2}$ 1999: Hrady a zámky na Moravě a ve Slezsku. Praha.

- 2001: Ilustrovaná encyklopedie moravských hradů, hrádků a tvrzí. Praha.

ŠABATOVÁ, L.-SOUKUP, M. B.-KYNCL, T., 2010: Nové poznatky z průzkumů hradu Rokštejn - Neue Erkenntnisse aus den Untersuchungen der Burg Rokštejn. In: Dějiny staveb. Sborník př́íspěvků z konference Dějiny staveb 2009, 193-209. Plzeň.

USTOHAL, V., 2003: Ochranné kroužkové odění a jeho materiál. In: Ve službách archeologie IV. Sborník k 75. narozeninám prof. PhDr. Vladimíra Nekudy, DrSc., 232-238. Brno.

USTOHAL, V.-STRÁNSKÝ, K., 1993: Rozměrová a materiálová analýza hákovnice a píštaly, CB 3, $282-288$.

VINǍ̌, J., 2011: Hrad Rokštejn. Oprava a konzervace v letech 2002-2010 - Die Burg Rokštejn. Ihre Restaurierung und Konservierung in den Jahren 2002 bis 2010, AH 36, 51-60.

VOHRYZEK, S., 2012: Střížovci v 2. polovině 14. století - The House of Stř́ižov in the 2nd half of the 14th century, Archeologické výzkumy na Vysočině 3, 67-74.

\section{Zusammenfassung}

\section{Revitalisierung der Burgruine Rokštejn und Perspektiven für ihre kulturelle Nutzung}

Im Jahr 1981 wurde wegen des damals geplanten Bauvorhabens einer Talsperre in Stř́žov auf Burg Rokštejn bei Panská Lhota (Stadt Brtnice, Bezirk Jihlava, Mähren) eine Rettungsgrabung durchgeführt. Zum Bau der Talsperre ist es glücklicherweise nicht gekommen. Gleichzeitig wurden Maß- 
nahmen zum Schutz und zur Erhaltung der Natur und der romantischen Szenerie der zwischen dem Pirnitzer Bachtal und der Stadt Brtnice (Pirnitz) gelegenen Landschaft getroffen. Im vorliegenden Beitrag werden die Geschichte der Burg und der Verlauf der Grabungsarbeiten bis zur Gegenwart (insgesamt 33 Saisons), die Ziele des Projekts und seine Ergebnisse, eine Beschreibung der Fundstelle, die bauliche Entwicklung der Burg (Phase IA und I B, II, III und IV) sowie eine Übersicht der Eigentümer (erste Erwähnung 1289, dann nach 1350 bis Ende 14. Jahrhundert im Besitz der Luxemburger Sekundogenitur, danach ging sie in den Besitz der Wallensteins über) vorgestellt.

Höchstwahrscheinlich wurde sie während den Hussitenkriegen zerstört und aufgegeben, wofür die Zeitspanne von 1423-1436 in Betracht kommt und sie damals wohl nicht ganz abgerissen wurde, wie aus ihrem Erhaltungsgrad hervorgeht. Offenbar wurde sie in der Zeit zwischen 1440 und 1450 notdürftig gesichert (Phase IV). Aus den fünfziger Jahren des 15. Jahrhunderts und vom Beginn der sechziger Jahre existieren einige schriftliche Dokumente, die entweder direkt auf der Burg entstanden, oder an die Burg gerichtet waren. Das Zentrum der Wallensteinschen Grundherrschaft verlagert sich nach Brtnice. Da die beschädigte Burg der Entwicklung der Feuerwaffen aus militärischer Sicht nicht mehr genügte, baute sich Wallenstein direkt in der Marktgemeinde Brtnice eine neue Burg, und Rokštejn wurde ihrem Schicksal überlassen. Der Bau in Brtnice ist durch eine an Markgraf Albrecht gerichtete Beschwerde der Iglauer Bürger von 1436 belegt.

Die archäologische Grabung förderte eine beträchtliche Anzahl an Denkmälern der mittelalterlichen Sachkultur zutage, lieferte aber auch Ökofakten.

Der beträchtliche Umfang der erhaltenen Baumasse der Ruine und die Bedeutung, welche die Fundstelle im regionalen Kontext, im Rahmen der nationalen Geschichte aber auch in Bezug zu Mitteleuropa einnimmt, machten ihre denkmalpflegerische Wiederherstellung erforderlich. Dies ist auch wegen des Besucherbetriebs notwendig. Deshalb wurde in den Jahren 2000-2002 auf Anregung des Stadtamts Brtnice und des damaligen Bürgermeisters der Gemeinde das Projekt „Konservierung und Stabilisierung der Konstruktionen von Burg Rokštejn“ ausgearbeitet. Das Referat Denkmalinspektion des Minsiteriums für Kultur der Tschechischen Republik in Prag stand dem Projekt beratend zur Seite, mit seiner Realisierung wurde dann im Jahr 2003 begonnen.

Das Denkmalschutzkonzept kommt den gegenwärtigen Vorstellungen der Denkmalpflege in höchstem Grade nahe, trägt aber auch den finanziellen Ansprüchen Rechnung, weswegen seine Umsetzung nicht unnötig verschwenderisch vonstatten gehen soll. Die Art und Weise der Instandsetzungsarbeiten ist der historischen Authentizität und dem Flair der Ruine untergeordnet, wobei die Beibehaltung des Umfangs ihrer Baumasse berücksichtigt wird. Aus diesem Grund wird bei der Konservierung bzw. Stabilisierung der gefährdeten Konstruktionen und des von den Archäologen freigelegten Mauerwerks sensibel vorgegangen. Ferner umfasst das Programm die Drainagierung des Mauerwerks und - besonders was die großräumigen Flächen anbelangt - eine geeignete Kanalisierung der Niederschläge sowie die Präsentation der archäologischen Situation und die Regelung des Besucherbetriebs. Die letzte Forderung lässt sich nur erfüllen, wenn der Zutritt von allen Seiten her eingeschränkt wird. Leicht anders geartet sind die Forderungen zum Schutz der im Areal freigelegten archäologischen Denkmäler (z.B. ihre Hervorhebung), die bei jedem Objekt eine sensible und individuelle Vorgehensweise erfordert, die im Sinne von A. Riegls und M. Dvořáks Überlegungen den „Wert des Alters“ respektieren muss. Nach den im Jahr 2000 erfolgten Sitzungen der Fachorgane des Denkmalschutzes, der Stadtvertreter und des Instituts für Archäologie und Museologie der Philosophischen Fakultät der Masaryk-Universität Brünn, auf denen das Projekt erörtert und genehmigt wurde, empfahl das Referat für Denkmalinspektion des Ministeriums für Kultur der Tschechischen Republik Herrn Ing. J. Vinař als Berater und technische Aufsicht, dessen Aufgabe darin besteht, die Arbeitsabläufe zu koordinieren, ihre Reihenfolge festzulegen und die technischen Lösungen entsprechend den neu erschlossenen Tatsachen anzupassen.

Die nach den Vorgaben des Denkmalschutz durchgeführte Sicherung umfasst eine Stabilisierung und Fixierung der gefährdeten vertikalen Baumasse mit statischen Methoden, wobei optisch störende Elemente auf ein Mindestmaß reduziert werden sollen. Dies betrifft hauptsächlich die östlichen Teile der Nord- und Südwand des oberen Palas. Die Nordwand wurde durch einen Mauerverband mit der stabilen Westwand fixiert, und durch Auskeilen wurde eine Schräglage der Südwand verhindert. Eine Festigung des Mauerwerks und der gefährdeten Mauerfluchten wird dadurch erzielt, indem Hohlräume und Fehlstellen mit Mauerwerk ausgefüllt werden. Bei den Reparaturen der seitlichen Bruchflächen konnte der Charakter des Mauerwerksverbands bewahrt werden. Davon betroffen 
waren hauptsächlich der untere Turm und die Hohlräume in der Wehrmauer der oberen Burg. Die Mauerwerkskronen wurden dadurch gesichert, indem verwitterter Mörtel durch frischen Mörtel oder eine Vermauerung ersetzt wurde, zu einer Einebnung von Mauern ist es nur minimal gekommen. Die Kronen hoher und schmaler Mauerwerke wurden mit Bleiblech ausgekleidet, und breite niedrige Mauern wurden mit einer Grasnarbe versehen. Für die Sicherung der Mauerwerkskronen beider Palasse, der nördlichen Wehrmauer und beider Türme sowie zur Fixierung der Innenputze wurde ein Innengerüst aufgebaut. Die gesäuberten und mit Kalkwasser konservierten Putze im Westteil des oberen Palas werden durch die kleinen Pultdächer des letzten Stockwerks vor Regenwasser geschützt. Die Gespärre ruhen auf Mauerlatten, die auf in den Aussparungen für die vormaligen Balken gelagerten Holzblöcken verankert sind und teilweise auch mit chemischen Ankern befestigt wurden. Wegen den Niederschlägen wurden auch die Kamintorsi und deren Rauchzüge abgedeckt. Als Dachbelag dient hier patiniertes Zink-Titan-Blech. Dienste und Bögen wurden lediglich mit traditionellen Methoden und Materialien gesichert. Die Bögen des Palas und das südliche Turmfenster der oberen Burg wurden ausgekeilt und an ihrer Oberseite gesichert. Die Instandsetzung der archäologischen Objekte passt sich dem ursprünglichen Mauerwerk an, und um die Zusammenhänge zu verstehen, ließ man einige Mauern andeutungsweise an die Oberfläche treten, um sie sichtbar zu machen. Für die im oberen Turm eingefügten Holzkonstruktionen wurden teilweise die Aussparungen für die ursprünglichen Balken genutzt, die Innentreppe ist selbsttragend, ebenso die ins erste Stockwerk führende Außentreppe. Die Dachkonstruktion des Turms wird durch den eingebauten flachen Fußboden gebildet, und vertikal ist das erste Stockwerk mit dem Dachboden durch eine einarmige Leitertreppe miteinander verbunden.

Die Lücken in den äußeren Wehrmauern der Burg wurden (zwecks Zugangsbeschränkung) lediglich mit Steinen geschlossen, wobei die Höhe über dem Außengelände nicht höher als 2,5 m betragen sollte. Auch die Westmauer des unteren Palas wurde auf gleiche Höhe gebracht, und die zwischen ihm und der oberen Burg liegende Mauer wird andeutungsweise komplettiert. Nach Beendigung der Grabungs- und Sicherungsarbeiten auf Burg Rokštejn rechnet man in der Tourismussaison mit einer kulturellen Nutzung der Burg, ebenso auch damit, dass sie zu Erholungszwecken dient und von Besuchern aufgesucht wird, die sie kennenlernen möchten. Der dadurch zu erwartende erwirtschaftete Ertrag dürfte während der Tourismussaison die Kosten für die Aufsicht und zumindest auch für eine Grundinstandhaltung decken.

Die Reihenfolge der für eine Nutzung der Burgruine Rokštejn erforderlichen Konservierung und Instandsetzung ergibt sich auch aus dem Gefährdungsgrad bestimmter Teile der Burg. Wegen der langfristig angelegten Realisierung und dem im voraus nicht abzusehenden jeweiligen Umfang und Aufwand der Arbeiten, werden die dazu erforderlichen Gelder erst jeweils nach Bedarf beschafft, je nach den finanziellen Möglichkeiten der Stadt und den vom Landkreis oder vom Ministerium für Kultur gewährten Zuschüssen. Die Reihenfolge der jeweiligen Tätigkeiten wurde bisweilen abgeändert, da beispielsweise die Gefährdung des oberen Palas in einem Statikgutachten als akut bezeichnet wurde. Aus den Forderungen des Denkmalschutzes ging auch ein Antrag hervor, Rokštejn zu einer Schutzzone erklären zu lassen, die gleichzeitig auch breitere Naturschutzinteressen respektiert.

Die vorliegende Studie ist ein Arbeitsergebnis des Projektes Historische Nutzung der Landschaft der Böhmisch-Mährischen Höhe in der Urzeit und im Mittelalter des Programms Angewandte Forschung und Entwicklung einer nationalen kulturellen Identität NAKI DF13P010VV005.

prof. PhDr. Zdeněk Měř́nský, CSc., Ústav archeologie a muzeologie Filozofické fakulty Masarykovy univerzity, Arna Nováka 1, 60200 Brno, Česká republika, merinsky@phil.muni.cz

doc. Ing. PhDr. Miroslav Plaček, Ústav archeologie a muzeologie Filozofické fakulty Masarykovy univerzity, Arna Nováka 1, 60200 Brno, Česká republika, mplaczek@seznam.cz 
